\title{
ADVANCING THE SEARCH FOR COMPROMISE: A RESPONSE TO PROFESSOR HYNES
}

\author{
Allan W. Vestal* \\ INTRODUCTION
}

In his article ${ }^{1}$ Professor Hynes makes several contributions to the debate over the Revised Uniform Partnership Act ("RUPA"). ${ }^{2}$ One contribution is his acknowledgement that both the contractarian and fiduciary-based positions have merit and respond to socially valuable, although competing, impulses-efficiency and individual justice. ${ }^{3}$ Both are important considerations, and we should therefore more seriously discuss the costs of both positions.

Another contribution by Professor Hynes is his observation that RUPA is internally contradictory and does not consistently adopt either position. ${ }^{4}$ The literature is now replete with critiques of RUPA from both the right and the left, which amply demonstrate that the uniform act does not meet either side's objectives. $^{5}$

\section{Copyright $(\mathbb{C} 1995$ by Law and Contemporary Problems}

* Associate Professor, Washington and Lee University School of Law.

The assistance of the Frances Lewis Law Center, Washington and Lee University, is gratefully acknowledged. I would like to thank David Caudill and Brenda Lynch Vestal for their helpful comments on earlier drafts. I would also like to thank my research assistants Barbara Jane League and Steve Powell for their valuable contributions.

1. J. Dennis Hynes, Fiduciary Duties and RUPA: An Inquiry Into Freedom of Contract, 58 LAW \& CONTEMP. PROBS. 29 (1995).

2. REVISED UNIF. PARTNERShIP ACT (last amended 1994), 6 U.L.A. 280 (Supp. 1995).

3. Hynes, supra note 1 , at $31,43-44,45-46,51-52$.

4. Id. at $35,37-38$.

5. See, e.g., Claire Moore Dickerson, Is it Appropriate to Appropriate Corporate Concepts: Fiduciary Duties and the Revised Uniform Partnership Act, 64 U. CoLO. L. REV. 111 (1993); Hynes, supra note 1; J. Dennis Hynes, The Revised Uniform Partnership Act: Some Comments on the Latest Draft of RUPA, 19 FLA. ST. U. L. REV. 727 (1992); Larry E. Ribstein, The Revised Uniform Partnership Act: Not Ready for Prime Time, 49 Bus. LAW. 45 (1993); Allan W. Vestal, Fundamental Contractarian Error in the Revised Uniform Partnership Act of 1992, 73 B.U. L. REV. 523 (1993) [hereinafter Vestal, Contractarian Error]; Allan W. Vestal, Choice of Law and the Fiduciary Duties of Partners Under the Revised Uniform Partnership Act, 79 IA. L. REV. 219 (1994) [hereinafter Vestal, Choice of Law]; Allan W. Vestal, Should the Revised Uniform Partnership Act of 1994 Really be Retroactive?, 50 Bus. LAW. 267 (1994) [hereinafter Vestal, Retroactive]; Allan W. Vestal, The Disclosure Obligations of Partners Inter Se Under the Revised Uniform Partnership Act of 1994: Is the Contractarian Revolution Failing?, 36 WM. \& MARY L. REV. 1559 (1995) [hereinafter Vestal, Contractarian Failing]; Allan W. Vestal, A Comprehensive Uniform Limited Partnership Act? The Time Has Come, 28 U.C. DAVIS L. REV. 1195 (1995) [hereinafter Vestal, CULPA].

RUPA participants have done a good job of defending their work. See, e.g., John W. Larson, et al., Revised Uniform Partnership Act Reflects a Number of Significant Changes, 10 J. PARTNERSHIP TAX'N 232 (1993); Edward S. Merrill, Partnership Property and Partnership Authority Under the Revised Uniform Partnership Act, 49 Bus. LAw. 83 (1993); Donald J. Weidner \& John W. Larson, The Revised 
Perhaps Professor Hynes's most significant contribution is the suggestion that the time has come to search for a compromise pursuant to which we can reform partnership law to respond to both sets of concerns. ${ }^{6}$ I agree that we need to resolve this impasse through compromise. ${ }^{7}$

To advance the search for a compromise solution, Professor Hynes critiques RUPA and suggests specific modifications of the statute. Although I find his critique and proposed modifications unpersuasive, the process of evaluating his critique and proposal should advance the larger discussion.

The core of Professor Hynes's article is his discussion of the waivability of fiduciary duties under RUPA. His basic argument is straightforward:

(1) Under the present, UPA-based regime, the fiduciary obligations of partners inter se are subordinate to the contrary agreement of the partners (at least arguably, in some jurisdictions).

(2) Under the proposed, RUPA-based regime, the fiduciary obligations of partners inter se are mandatory and superior to the contrary agreement of the partners.

(3) The creation of such mandatory fiduciary duties greatly-and inappropriately, given the underlying policy of RUPA - restricts the freedom of contract of partners and results in a diminution of certainty and reliability of partner agreements.

(4) Adequate protections can be provided if the fiduciary duties made mandatory under RUPA are made default rules and reliance is placed on contract doctrines, such as unconscionability, and the nonfiduciary obligation of good faith under RUPA.

I find troublesome each of these four steps. Part II of this response to his analysis argues that the overwhelming consensus of the cases and commentaries on the existing regime of partnership law supports the proposition that the existing fiduciary duties of partners inter se are essentially mandatory, not default, rules. Part III argues that, properly read, the fiduciary duties and the nonfiduciary obligation of good faith and fair dealing under RUPA are not mandatory in any meaningful sense of the word, but rather are essentially default rules. Part IV challenges on policy grounds the decision favoring the certainty and reliability of partner agreements over the traditional, fiduciaryoriented goal of individual justice. Part $\mathrm{V}$ questions whether the protections asserted by Professor Hynes to be found in the good faith and fair dealing standard in RUPA and the contract-based unconscionability standard would be

Uniform Partnership Act: The Reporters' Overview, 49 Bus. LAw. 1 (1993).

6. Hynes, supra note 2, at 50, 54. In an earlier version of his article, Professor Hynes concluded that his proposal "may be the best compromise available." J. Dennis Hynes, Fiduciary Duties and RUPA: An Inquiry Into Freedom of Contract (Feb. 22, 1995)(unpublished draft, on file with Law \& Contemporary Problems).

7. I first proposed a compromise solution in 1991. Allan W. Vestal, "Ask Me No Questions and I'll Tell You No Lies": Statutory and Common-Law Disclosure Requirements Within High-Tech Joint Ventures, 65 TUL. L. REV. 705, 769-73 (1991). 
an adequate substitute for a true fiduciary regime. The conclusion outlines an alternative structure for a compromise that could resolve the contractarianfiduciary impasse in general partnership law.

II

\section{Contractarian Paradise Found? The MYTH of Default Fiduciary Duties IN THE EXISTING REgIME}

The casual reader of Professor Hynes's article might come away with the impression that the mandatory fiduciary duties established under RUPA would change existing law, removing partners from a contractarian state of grace to a fiduciary state of corruption. Professor Hynes frames the matter by observing:

The issue of defining limits on the power to vary fiduciary duties by contract is not new. RUPA arguably would change existing law in some jurisdictions. Case authority exists under the UPA that recognizes the primacy of the partnership agreement, even when substantial inroads into fiduciary duties are at issue. ${ }^{8}$

He follows with an extended discussion of two cases, Singer $v$. Singer ${ }^{9}$ and Riviera Congress Associates v. Yassky, ${ }^{10}$ which he concludes with the assessment that "[a]dopting RUPA would make an inroad into the bargaining principle established by those courts."11

8. Hynes, supra note 2 , at 41 .

9. 634 P.2d 766 (Okla. Ct. App. 1981).

10. 223 N.E.2d 876 (N.Y. 1966).

11. Hynes, supra note 2, at 43. Professor Hynes believes that neither Singer nor Riviera could withstand adoption of RUPA. I suspect he is wrong, especially if the reviewing court adopts the confirmatory reading of RUPA $\S 103(\mathrm{~b})(3)$, see infra notes $47-85$ and accompanying text, rather than the restrictive reading of the section advanced by Professor Hynes, see infra note 46 and accompanying text. Even under the restrictive reading, the outcomes need not change. Professor Hynes's reading of Singer is that

[i]n Singer, the duty of loyalty was in effect abrogated by the partnership agreement. This would seem to call into play section $103(\mathrm{~b})(3)$, which forbids eliminating the duty of loyalty. Even if the provision in Singer was not found to eliminate altogether the duty of loyalty, one can easily imagine a court characterizing the language in the partnership agreement as manifestly unreasonable.

Hynes, supra note 2 , at 42 . But the Singer court specifically noted that the duty of loyalty was not completely eliminated by the Josaline partnership agreement, and that partner conduct in violation of the duty to account, for example, remained actionable. 634 P.2d at 772-73 ("Had [the defendants] pirated an existing partnership asset or used partnership funds or encumbered Josaline financially, our decision would be different."). So it is hard to argue the Josaline agreement provision would have run afoul of RUPA's prohibition of elimination. Nor does it seem likely the Singer court would have invalidated the provision as manifestly unreasonable. The Singer court, after all, found that the language of the Josaline agreement

is designed to allow and is uniquely drafted to promote spirited, if not outright predatory competition between the partners. Its strong wording leaves no doubt in our minds that its drafters intended to effect such a result. . . . We construe it to legitimize and extend free competition between the partners to partnership prospects and opportunities .... .

Id. at 772 . It is hard to see why the court would deem the same language manifestly unreasonable.

As to Riviera, Professor Hynes does not argue that the contract provision would run afoul of the prohibition of elimination, but only that

[o]ne can imagine a court operating under RUPA deciding that a provision such as the one involved in Riviera is manifestly unreasonable, on the theory that it imposes an 
The casual reader's impression, that RUPA moves partners from a contractarian world in which fiduciary duties are freely amendable to a fiduciary world in which they are mandatory, would be understandable even if not supported by a close reading of Professor Hynes's argument. ${ }^{12}$ Such an impression, however, does not survive an examination of the relevant commentary or case law under the UPA. ${ }^{13}$ Notwithstanding Singer ${ }^{14}$ and Riviera ${ }^{15}$ the body of commentary ${ }^{16}$ and case authority ${ }^{17}$ rejects the notion

unfair risk on the limited partners and operates too much to the advantage of the general partners.

Hynes, supra note 2, at 43 . Perhaps, but the Riviera court does not seem at all hostile to the general partners; it indicates, after all, that the limited partners had been

fully appraised in the prospectus that the defendant general partners intended to lease the premises to their own corporation and that such tenant would be capitalized at only $\$ 50,000$. This clear statement of purpose has the effect of "exonerating" the defendants, at least in part, "'from adverse inferences which might otherwise be drawn against them" simply from the fact that they dealt with themselves.

223 N.E.2d at 880 (quoting Everett v. Phillips, 43 N.E.2d 18, 22 (N.Y. 1942)). This does not strike one as the language of a court that would easily find the contract provision manifestly unreasonable.

12. Professor Hynes, after all, is careful to qualify his observation: "Case authority exists" from which it can be concluded that "RUPA arguably would change existing law in some jurisdictions." Hynes, supra note 2 , at 41 .

13. UNIF. PARTNERSHIP ACT (last amended 1914), 6 U.L.A. 1 (1969).

14. Singer v. Singer, 634 P.2d 766 (Okla. Ct. App. 1981). Technically, the Singer court's observations on the contractual modification of the duty of loyalty are dicta. Although Professor Hynes simplifies the case to "Josaline brought an action to have the land held in constructive trust for it," in fact the action was initiated not on behalf of the Josaline partnership, but on behalf of a different partnership allegedly including the plaintiffs, the Tractenbergs, and the defendants, which was asserted to have been formed pursuant to an oral agreement by, or on behalf of, the putative partners. Id. at 769. In part II of the opinion, the court found that the plaintiffs failed to prove the existence of the alleged partnership by the requisite standard of clear, unequivocal, and decisive evidence. Id. at 770-72. Only after the court makes this finding, which could have been dispositive of the action, does the opinion consider the effect of the Josaline partnership agreement. Id. at 772-73.

In their partnership treatise, Professors Bromberg and Ribstein suggest another reason to discount the importance of the Singer decision. They note the "strongly worded provision" in the Singer agreement, and suggest "[t]he court may reach the same result without an explicit agreement by holding that the narrow scope of the partnership permitted outside dealings." ALAN R. BROMBERG \& LARRY E. RIBSTEIN, BROMBERG AND RIBSTEIN ON PARTNERSHIP § 6.07, 6:90-:91 (1994).

15. Riviera Congress Assocs. v. Yassky, 223 N.E.2d 876 (N.Y. App. 1966). Riviera is remarkable mostly for what it is not. It is not a final denial of the limited partners' claims; it is simply a finding that summary judgment in their favor is not warranted. Id. at $\mathbf{8 8 0}$. Nor is Riviera an endorsement of broad contractual modifications of the fiduciary duty against self-dealing. The Riviera court's actual statement of the law is that "if the asserted self-dealing was actually contemplated and authorized, it would not, ipso facto, be impermissible and deemed wrongful." Id. This is a fair restatement, in the context of the Riviera facts, of the existing law that specific acts of self-dealing can be authorized if there is full disclosure and consent.

The assessment of Riviera by Professors Bromberg and Ribstein in their partnership treatise is interesting because it notes the limited holding:

In Riviera Congress Associates v. Yassky, a limited partnership case, the court held, relying on a corporate precedent, that a statement of purpose in the prospectus that permitted self-dealing had the effect of mitigating the presumption against defendants and so precluded summary judgment for plaintiffs.

BROMBERG \& RIBSTEIN, supra note 14, at 6:92.

16. Vestal, Contractarian Error, supra note 5, at 524-26. The pre-UPA commentaries treat the core of the partnership relation, the duties and obligations of partners inter se, as a matter of status, not contract. Thus, one treatise discusses "the various duties of partners, which are usually contained in the articles, but which necessarily arise from their connection." JOHN COLLYER, A PRACTICAL 
TREATISE ON THE LAW OF PARTNERSHIP 205 (4th Am. ed. 1853). The fiduciary duties formed the core of the relationship: "The duty of each partner to exercise toward the others the highest integrity and good faith is the very basis of their mutual rights in all partnership matters." EUGENE A. GILMORE, HANDBOOK ON THE LAW OF PARTNERSHIPS, INCLUDING LIMITED PARTNERSHIPS 375 (1911).

Modern, post-UPA commentaries affirm the analysis: "The status of partners as fiduciaries with respect to the partnership and each other is an established principle of partnership law." J. WILLIAM CAllison, PARTNERShIP LAW AND PRACTICE 12-1 (1993). "One of the most significant aspects of the partnership relation is its fiduciary character." HAROLD G. REUSCHLEIN \& WILLIAM A. GREGORY, THE LAW OF AGENCY AND PARTNERSHIP \$ 188, at 278 (2d ed. 1990). Professor Melvin Eisenberg's two letters, mentioned by Professor Hynes, are additional authority. Letter from Melvin A. Eisenberg to The Commissioners on Uniform State Laws (July 27, 1992) (on file with the author); Letter from Melvin A. Eisenberg to The Commissioners on Uniform State Laws (July 17, 1992) (on file with the author).

Not even a commentary authored by a prominent proponent of partnership contractarianism argues that under the present regime the weight of general partnership precedent supports the proposition that parties are free to enter into a general, contractual modification of their fiduciary duties. BROMBERG \& RIBSTEIN, supra note 14, at pt. 6. The authors start with the general proposition that "[ $t$ ]he Uniform Partnership Act serves as a 'standard form' contract, which controls the rights and duties among the partners in the absence of contrary agreement." Id. $\S 6.01$, at $6: 2$. From that statement, one might incorrectly conclude that the authors believe the UPA serves as a fully amendable standard form contract for the fiduciary duties among partners. The discussion of the fiduciary duties of partners begins on a traditional note, with the general proposition that "[ $\mathrm{t}$ ]he partners, among themselves, are fiduciaries," id. $\$ 6.07$, at $6: 67$, and a recognition that "specific duties and restrictions ... are imposed on the partners by reason of the fiduciary nature of their relationship," id. at 6:67-:68. But the analysis takes a contractarian turn with the assertion that "[f]iduciary duties are essentially part of the standard form contract that governs partnerships in the absence of contrary agreement." Id. at 6:68. The authors finesse the mandatory-default nature of fiduciary duties under the existing regime, $i d$. at $6: 73$, by citing only the UPA $\$ 21$ obligation to account, which by its terms applies only to "profits derived . . . without the consent of the other partners . ..."UPA $\$ 21,6$ U.L.A. at 258. The issue of whether the present regime has mandatory fiduciary duties that are subject to specific limited waivers, or default fiduciary duties that are subject to blanket modification, is finally discussed at the end of Bromberg and Ribstein's treatment. The initial thrust of their analysis is contractarian: "Partner fiduciary duties are aspects of the 'standard form' of partnership. As with respect to the other rights and duties among the partners, the partners may alter the standard form fiduciary duties to suit their particular relationship." BROMBERG \& RIBSTEIN, supra note $14, \S 6.07$ at $6: 89$. But the text then speaks of the UPA $\S 21$ consents which are specific in content and undoubtedly enforceable. On the critical question of general amendments of the "default" provisions, the commentary is equivocal:

Although a partner may retain a benefit where the other partners consented to the particular transaction or the agreement permitted a certain type of co-partner profit, an across-the-board waiver presents a more serious question. Because the fiduciary duty among the partners is so basic a part of the partnership standard form, a court may interpret an across-the-board waiver strictly and apply even a clear waiver cautiously.

There is some authority for nonenforcement or incomplete enforcement of such waivers in the corporate and limited partnership contexts. ...

Despite the corporate and limited partnership authority hostile to broad waivers of fiduciary duty, such waivers should arguably be enforced in a general partnership where there is direct and equal dealing between the partners and co-management power, at least where the waiver is explicit and there are no equitable reasons for nonenforcement in the given case.

Id. at 6:91-:92 (emphasis added, citations omitted). That such general modifications "should arguably be enforced" is an argument from policy, not precedent. No reference is made to the general partnership cases and commentary rejecting general, contractual modifications of partners' fiduciary duties inter se.

17. E.g., Saballus v. Timke, 460 N.E.2d 755 (Ill. App. Ct. 1983) (general partnership); Appletree Square I Ltd. Partnership v. Investmark, Inc., 494 N.W.2d 889, 893 (Minn. Ct. App. 1993) (limited partnership obligation to disclose information); Labovitz v. Dolan, 545 N.E.2d 304, 310 (IIl. App. Ct. 1989) (limited partnership). 
that partners exist in a contractarian state of grace as to fiduciary duties under the UPA. ${ }^{18}$

\title{
III
}

\section{Contractarian Paradise lost? The (Probable) Myth of MANDATORY FIDUCIARY DUTIES IN RUPA}

If Professor Hynes creates a mistaken impression as to where partners start out on the existing fiduciary-contractarian continuum, he also leaves what is probably a mistaken impression as to where RUPA places partner relations inter se. He begins, appropriately, by noting that RUPA contains the first express, general recognition of the fiduciary role of partners, ${ }^{19}$ since the UPA recognizes only one aspect of partners' fiduciary duties and leaves the other aspects to the common law. ${ }^{20} \mathrm{He}$ also notes the inclusion of a statutory obligation of good faith and fair dealing. ${ }^{21}$ Professor Hynes's final point concerns the waivability of fiduciary duties under RUPA: "the waivability of these duties in the partnership context, never before addressed by statute, is covered in section 103 of RUPA, which prohibits waiver of the duties described in section 404."22

The impression, which is probably mistaken, comes in the final point of Professor Hynes's analysis: his conclusion that RUPA creates mandatory

\begin{abstract}
It is no answer to the claim that plaintiffs make in this case that partners have the right to establish among themselves their rights, duties and obligations, as though the exercise of that right releases, waives or delimits somehow, the high fiduciary duty owed to them by the general partner-a gloss we do not find anywhere in our law. On the contrary, the fiduciary duty exists concurrently with the obligations set forth in the partnership agreement whether or not expressed therein. Indeed . . . although "partners are free to vary many aspects of their relationship inter se, ... they are not free to destroy its fiduciary character."
\end{abstract}

Id. (citing Saballus v. Timke, 460 N.E.2d, 755, 759 (1983) (citing HAROLD GILl REUSCHLEIN \& WILlIAM A. GREGORY, HANDBOOK ON THE LAW OF AGENCY AND PARTNERSHIP 267 (1970))).

18. Unfortunately, the reader is only told in a footnote at the end of the discussion of Singer and Riviera of the existence of contrary authority. Hynes, supra note 2, at $43 \mathrm{n} .72$ ("Of course, cases exist that hold diferrently, refusing to recognize provisions in a partnership agreement that make substantial inroads into fiduciary duties." (citing Appletree Square I Ltd. Partnership v. Investmark, Inc., 494 N.W.2d 889 (Minn. Ct. App. 1993))).

19. Hynes, supra note 2, at 29-30. A quibble perhaps, but Professor Hynes's citation of my earlier work is a bit misleading. The cited text refers not to the inclusion of a comprehensive definition of partner fiduciary duties under RUPA § 404(a), of which I am also critical. Vestal, Contractarian Error, supra note 5, at 537-45. Rather, the cited language refers to the "rejection of the fiduciary essence of the partnership relationship in favor of the contractarian premise" through the language of what became RUPA $\S 404$ (e) in the final version of the Act. Id. at 535, 553-55. RUPA $\$ 404(\mathrm{e}), 6$ U.L.A. at 313 (Supp. 1995) ("A partner does not violate a duty or obligation under this [Act] or under the partnership agreement merely because the partner's conduct furthers the partner's own interest.").

20. Hynes, supra note 2 , at 29 n.3.

21. Id. at 30.

22. Id. at 30. Although he speaks of "duties," Professor Hynes is presumably speaking of both the fiduciary duties of loyalty and care under $\$ 404$ (a)-(c) and the nonfiduciary obligation of good faith and fair dealing under $\S 404(\mathrm{~d})$. He is also presumably speaking of general waivers, since the UPA does contain authorization for specific waivers, "the consent of the other partners," in cases of self-dealing. UPA $\$ 21(1), 6$ U.L.A. at 258. 
fiduciary duties. The reality is much more complicated. ${ }^{23}$ Professor Hynes divides the universe of duties under section 404 into two parts: those duties that are "mandatory" and those that are "default rules." 24 According to Professor Hynes, "[i]f a rule is intended to apply regardless of the agreement of the partners, it is 'mandatory'." 25 Nonmandatory rules, which "can be changed by agreement of the partners," are "default rules." ${ }^{26}$. As Professor Hynes reads it, "section 103 of RUPA . . prohibits waiver of the duties described in section 404." 27 Thus, he concludes, "all fiduciary duties and the duty of good faith and fair dealing are classified as mandatory duties." ${ }^{28}$

Since "the waivability of duties owed by partners to each other ... is the primary focus of [his] article,"29 it is unfortunate Professor Hynes doesn't explain the provisions on waiver more fully. His discussion of the waiver provisions misses an important interpretive dispute regarding just how impervious to alteration the "mandatory" fiduciary provisions of RUPA truly are. The character of these provisions depends, in part, on whether one adopts a "restrictive" or a "confirmatory" reading of section 103(b). Under a restrictive reading, the mandatory fiduciary provisions of section 103(b) appear quite formidable since any categorical modifications are subject to a "manifestly unreasonable" test. The confirmatory reading is less formidable since it allows broad modifications without reference to the "manifestly unreasonable" test. The confirmatory reading is supported by both the organizational structure and text of RUPA, and by its drafting history.

\section{A. The False Dichotomy between Mandatory and Default Fiduciary Duties under RUPA}

As an initial matter, the text of RUPA does not use the "mandatory" and "default" nomenclature adopted by Professor Hynes, much less the definitions of those terms he advances. ${ }^{30}$ Strictly speaking, section 103 differentiates

23. Professor Hynes is not alone in this error. See Mark S. Kende, Shattering the Glass Ceiling: $A$ Legal Theory for Attacking Discrimination Against Women Partners, 46 HASTINGS L.J. 17, 54-55 n. 156 (1994) ("Vestal's view that RUPA substantially weakens the fiduciary duties of partners is incorrect, especially since RUPA makes the good faith duties of partners mandatory and permits partners to bring actions at law."); Michael L. Keeley, Note, Whose Partnership is it Anyway?: Revising the Revised Uniform Partnership Act's Duty-of-Care Term, 63 FoRDHAM L. REV. 609,615 n. 33 (“'Mandatory terms' are synonymous with 'nonwaivable provisions.' In the partnership context, this includes the duty of good faith and fair dealing. Mandatory terms cannot be contracted around no matter how honestly the parties desire it." (citing RUPA $\S 103($ b)(5), 6 U.L.A. at 288 (Supp. 1995))).

24. Hynes, supra note 2 , at 34 .

25. Id. at 34 n.19.

26. Id.

27. Id. at 30 .

28. Id. at 34 .

29. Id. at 31 .

30. As Professor Hynes correctly observes, the mandatory and default labels are used in the official commentary. Id. at $34 \mathrm{n} .19$ (citing RUPA $\$ 103 \mathrm{cmt} .1$ (1994)). The Reporters were careful, however, to tie the "mandatory" label to sections that "cannot be waived or varied by agreement beyond what is authorized." RUPA $\$ 103 \mathrm{cmt}$. 1, 6 U.L.A. at 288 (Supp. 1995)(emphasis added). 
between four different levels of modifications that are permitted, not two levels as the mandatory-default analysis suggests. As to most RUPA provisions-that is, those not listed in section 103(b) - the parties are free to amend the statutory provisions if they wish. ${ }^{31}$ As to those other provisions that are listed in section 103(b), the power of the partners to vary the statutory provisions is restricted to one of three standards. The strictest standard is where the partnership agreement may not "vary" ${ }^{32}$ or "restrict" ${ }^{33}$ specified statutory provisions. The intermediate standard is where the partnership agreement may not "unreasonably restrict" 34 or "unreasonably reduce" ${ }^{35}$ specified statutory provisions. The weakest standard is where the partnership agreement may not "eliminate" specified statutory provisions. ${ }^{36}$ The only two statutory provisions that fit into the third, weakest category are the fiduciary duty of loyalty ${ }^{37}$ and the nonfiduciary obligation of good faith and fair dealing. ${ }^{38}$ The parties may not "unreasonably reduce" the fiduciary duty of care, which thus receives an intermediate level of protection. ${ }^{39}$ There is every reason to believe the drafters knew exactly what they were doing and that the differences in the three categories are not accidental. There is also every reason to believe, as do the drafters, that the prohibition on mere "elimination" leaves the parties free to agree to a succession of restrictions that stop short—but just short-of total, formal elimination of the statutory provision while providing for its complete practical elimination. ${ }^{40}$

Loyalty, good faith, and fair dealing are not even "mandatory" within Professor Hynes's own definition. Under his analysis, "[i]f a rule is intended to apply regardless of the agreement of the partners, it is 'mandatory."'41 But neither the duty of loyalty nor the obligation of good faith and fair dealing is intended to apply "regardless of the agreement of the partners," since in both

31. Id. § 103(a), 6 U.L.A. at 288.

32. Id. $\S 103$ (b)(1), 6 U.L.A. at 288 ("partnership agreement may not . . vary the rights and duties under Section 105," with specified exception); id. § 103(b)(6), 6 U.L.A. at 288 ("partnership agreement may not ... vary the power to dissociate as a partner under section 602 (a)," with specified exception); id. \$ 103(b)(7), 6 U.L.A. at 288 ("partnership agreement may not . . vary the right of a court to expel a partner in the events specified in section 601(5)"); id. \& 103(b)(8), 6 U.L.A. at 288 ("partnership agreement may not ... vary the requirement to wind up the partnership business in cases specified in section $801(4)$, (5), or (6)").

33. Id. § 103(b)(9), 6 U.L.A. at 288 ("partnership agreement may not . . restrict rights of third parties under this [Act]").

34. Id. § 103(b)(2), 6 U.L.A. at 288 ("partnership agreement may not . . unreasonably restrict the right of access to books and records under section 403(b)").

35. Id. \& 103(b)(4), 6 U.L.A. at 288 ("partnership agreement may not . . unreasonably reduce the duty of care under section 404 (c) or 603(b)(3)").

36. Id. $\$ 103(\mathrm{~b})(3), 6$ U.L.A. at 288 ("partnership agreement may not . . eliminate the duty of loyalty under section 404 (b) or section $603(\mathrm{~b})(3)$ "); id. \& 103(b)(5), 6 U.L.A. at 288 ("partnership agreement may not ... eliminate the obligation of good faith and fair dealing under section 404(d)").

37. Id. $\$ 103(\mathrm{~b})(3), 6$ U.L.A. at 288.

38. Id. $\S 103(\mathrm{~b})(5), 6$ U.L.A. at 288.

39. Id. § 103(b)(4), 6 U.L.A. at 288.

40. Vestal, Contractarian Error, supra note 5, at 559 n.155.

41. Hynes, supra note 2, at 34 n.19. 
cases the partners can, through their agreement, make fundamental changes in the statutory provision. Under even the most restrictive reading, the parties may make categorical modifications of the duty of loyalty that are not manifestly unreasonable, ${ }^{42}$ may reduce the duty of care as long as the reduction is not unreasonable, ${ }^{43}$ and may define the standards by which the obligation of good faith and fair dealing are to be measured, if such standards are not manifestly unreasonable. ${ }^{44}$ Under Professor Hynes's test, the only truly mandatory rules are those that the parties cannot "vary" or "restrict." 45

If section 103(b)(3) simply read "[t]he partnership agreement may not . . . eliminate the duty of loyalty under section 404(b) or 603(b)," the use of "eliminate" and the contrast with the treatment of other sections would end the inquiry. The complicating factor, however, is that the section goes on:

The partnership agreement may not ...

(3) eliminate the duty of loyalty under Section 404 (b) or 603(b), but:

(i) the partnership agreement may identify specific types or categories of activities that do not violate the duty of loyalty, if not manifestly unreasonable; or

(ii) all of the partners or a number or percentage specified in the partnership agreement may authorize or ratify, after full disclosure of all material facts, a specific act or transaction that otherwise would violate the duty of loyalty .... ${ }^{46}$

How should the two subsidiary clauses be interpreted? The first question is how the "manifestly unreasonable" language operates. There are two distinct possibilities: a restrictive reading and a confirmatory reading. Professor Hynes and others seem to adopt what I will call a restrictive reading of the section. They evidently believe that the "manifestly unreasonable" standard is a restriction on all modifications of the fiduciary duty of loyalty and the obligation of good faith and fair dealing. Thus, they would paraphrase the relevant duty of loyalty language as:

The partnership agreement may not vary the duty of loyalty under section 404(b), but the partnership agreement may identify specific types or categories of activities that do not violate the duty of loyalty, if not manifestly unreasonable, and the partnership agreement may establish a mechanism for less than unanimous specific waivers.

Under such a reading, the "manifestly unreasonable" qualifier becomes critically important, and it makes sense, from the contractarian perspective, to try to weaken the formulation by moving to an unconscionability test. The alternative reading, which $I$ will term the confirmatory reading, is that the "eliminate" language of the initial part of section 103(b)(3) means what it says, and that the subsidiary clauses merely confirm and regulate two important ways in which the

42. RUPA § 103(b)(3)(i), 6 U.L.A. at 288.

43. Id. $\S 103(\mathrm{~b})(4), 6$ U.L.A. at 288.

44. Id. \$103(b)(5), 6 U.L.A. at 288.

45. Id. $\S 103$ (b)(1), (6), (7), (8), (9), 6 U.L.A. at 288.

46. Id. $\$ 103(\mathrm{~b}), 6$ U.L.A. at 288. 
power of modification may be exercised. The confirmatory reading of the section could be as follows:

The partnership agreement may not completely eliminate the duty of loyalty under section 404(b), although it may make changes short of complete elimination. The partnership agreement may identify specific types or categories of activities that do not violate the duty of loyalty, if such categorical exceptions are not manifestly unreasonable, and may establish a mechanism for less than unanimous specific waivers.

\section{B. The Textual Argument for a Confirmatory Reading}

Which reading, the restrictive or the confirmatory, is correct? In all candor, the language of the statute is not precise, and substantial arguments exist for both sides. On balance, however, a stronger case can be made for the confirmatory reading.

First, the confirmatory reading comports better than the restrictive reading with the underlying organizational scheme of RUPA. As Professor Hynes observes, the drafters of RUPA clearly endorsed freedom of contract of the participants-his bargain principle. ${ }^{47}$ Thus, every statutory provision in RUPA, if not mentioned in section 103(b), is subject to unlimited modification at the agreement of the parties. It makes sense, then, that as to the exceptions to the general rule--the provisions as to which the power to modify is restricted-the statutory restrictions should be narrowly construed so as to maximize the parties' freedom of contract. ${ }^{48}$ This is consistent with the confirmatory reading, which treats the subsidiary clauses of section $103(\mathrm{~b})(3)$ and (5) as noting specific types of ways in which the duty of loyalty and the obligation of good faith and fair dealing can be modified short of elimination, but not as limiting the types of such modifications.

The second argument for the confirmatory reading is that it is more compatible with the language employed than is the restrictive reading. We start with the necessary assumption that the drafters meant to indicate substantive differences by their use of the terms "vary,"49 "restrict,"50 "unreasonably restrict," "un "uneasonably reduce,"52 and "eliminate" sions of section $103(\mathrm{~b}) .{ }^{54}$ The confirmatory reading honors the drafters' word

47. Id. \$ 103(a), 6 U.L.A. at 288 ("Except as otherwise provided in subsection (b), relations among the partners and between the partners and the partnership are governed by the partnership agreement."); Hynes, supra note 2, at 37, 40-41.

48. One would expect Professor Hynes to support this reading: "The drafters of RUPA made an effort to keep the list of mandatory rules as narrow as possible . . . " See Hynes, supra note 2, at 34.

49. RUPA \& 103(b)(1), (6)-(8), 6 U.L.A. at 288.

50. Id. $\S 103(\mathrm{~b})(9), 6$ U.L.A. at 288 .

51. Id. $\$ 103(\mathrm{~b})(2), 6$ U.L.A. at 288 .

52. Id. \$103(b)(4), 6 U.L.A. at 288.

53. Id. § 103(b)(3), (5), 6 U.L.A. at 288.

54. This is not to say that the drafters were always careful in their use of terms. Confusion over nomenclature was evident in the floor debates. For example, the Chair of the RUPA drafting committee introduced the discussion of the proposal to protect the duty of loyalty from elimination by 
choice; the restrictive reading does not. For the restrictive reading to work, the word "eliminate" in section 103(b)(3) must be read to mean "vary," a meaning presumably not intended by the drafters. 55

A third argument in favor of the confirmatory reading concerns the placement of the "manifestly unreasonable" qualification. If the word "eliminate" means eliminate and not vary, and if, as the restrictive reading suggests, the manifestly unreasonable qualification was meant to apply to all modifications of the statutory duty of loyalty, the qualification is misplaced. To apply to all modifications, the manifestly unreasonable qualifier should modify "eliminate" and not merely the categorical exception language. ${ }^{56}$

A related fourth argument in favor of the confirmatory reading arises from the content of the first subsidiary clause of section 103(b)(3). Under the restrictive reading, the subsidiary clause imposes a "manifestly unreasonable" test on all modifications of the duty of loyalty; however, the clause does not deal in terms of "all modifications." It is cast in terms of partnership agreement provisions that "identify specific types or categories of activities that do not violate the duty of loyalty ...."57 But not all possible modifications of the duty of loyalty would be cast in terms of "specific types or categories of activities." For example, parties might desire to limit the duty of loyalty temporally, such as changing the adverse interest prohibition under section 404 (b)(2) by making it inapplicable during the winding up period. ${ }^{58}$ Alternatively, the parties might desire to engage in nonspecific modifications of the duty of loyalty, such as eliminating completely the noncompetition prohibition of section 404(b)(3). The language of the categorical modification clause does not, by its terms, limit the parties' ability to enter into such modifications which, after all, fall short of elimination of the duty of loyalty.

\section{The Drafters' Intent and the Confirmatory Reading}

If the "manifestly unreasonable" qualifier is not intended to be general, as the restrictive reading would suggest, how does the confirmatory reading deal with the nonuniformity of having specific categorical limitations, but not other

using the term "nonwaivable." Proceedings of the National Conference of Commissioners on Uniform State Laws, Uniform Partnership Act, Proceedings of the Committee of the Whole, July 31-Aug. 6, 1992, at 397 [hereinafter 1992 National Conference Proceedings]. The same characterization was used by a committee member to describe the nonfiduciary obligation of good faith. Id. at 143 .

55. On the other hand, the word "but" does not easily fit the confirmatory reading. If one changed the word "eliminate" to "vary," the use of "but" would be appropriate. Under the present language, "and" is more appropriate than "but."

56. This would have been easily accomplished:

(b) The partnership agreement may not: . . .

(3) eliminate the duty of loyalty under Section 404(b) or 603(b), but modifications of such duty may not be manifestly unreasonable, and consistent with such standard: . .

(i) the partnership agreement may identify specific types or categories of activities that do not violate the duty of loyalty, if . .

57. RUPA \& 103(b)(3)(i), 6 U.L.A. at 288.

58. Id. $\S 404$ (b)(2), 6 U.L.A. at 313 . 
modifications of the duty of loyalty, comply with the "manifestly unreasonable" test? An answer, suggested by a review of the history of the section ${ }^{59}$ and the floor debates, is that the discrepancy is the product of a flawed debate on the floor of the Conference which proceeded from several incorrect assumptions and resulted in imprecise language being added to the section. It is not a theoretically elegant argument, but it does resonate with the legislative history. ${ }^{60}$ We begin by noting that the mechanism that became section 103 -with statutory sections subject to modification by the parties unless the section is included on a list of sections as to which the power to modify is restricted-was included from the first version of RUPA. ${ }^{61}$ But the duty of loyalty was not included in the list until the July 1992 Conference meeting at which the first "final" version of RUPA was adopted. ${ }^{62}$ To that point, the official commentary reflected the drafters' intention that the fiduciary duties "may be waived or modified in the partnership agreement, since they are not

59. The process of drafting RUPA was long and complex. See Vestal, Retroactive, supra note 5 , at 269 n.10 (tracing history of RUPA and listing drafts).

60. I note that Professor Hynes's reconstruction of the legislative history of the 1992 Commissioners' meeting differs from my own. He casts the July 27, 1992, letter from Professor Melvin Aron Eisenberg as "[a] thunderbolt from Berkeley" which "had a powerful impact on the [National Conference of Commissioners on Uniform State Laws]." Hynes, supra note 2, at 36-37. While I completely agree with the substance of Professor Eisenberg's critiques of RUPA, and wish his analysis had had a greater impact, I was at the San Francisco meeting in both the plenary sessions and the committee meetings on RUPA, and my recollection is that the fiduciary duty discussions were not particularly driven by the Eisenberg analysis. A review of the transcript of the plenary sessions reveals only three mentions of the Eisenberg letters. At one point a Commissioner asks for the drafting committee's response to Professor Eisenberg's correspondence, only to be told by the Chair that "the Committee of the Whole does not have any professor's correspondence on this subject . . ." 1992 National Conference Proceedings, supra note 54, at 171. Shortly thereafter, another Commissioner notes the drafting committee is proposing a move from classical notions of fiduciary duty to a default approach. He observes: “Now, that's a dramatic movement away from traditional notions, and you can tell how upset various people, including Professor Eisenberg and others who have spoken here, have been about this." Id. at 175. The final mention is when the same Commissioner notes that Professor Eisenberg's letter mentions the link between the general partnership law and the law of limited partnerships. Id. at 445-46.

A review of the transcripts of the plenary sessions reveals that the nonfiduciary characterization of the obligation of good faith was the first concern, with the assembly rejecting a move to recharacterize the duty of good faith as a fiduciary duty. Id. at 141-50. Then the assembly considered the content of the duty of care and discussed a motion from the floor to add a "manifestly unreasonable" qualifier to the duty of care. Id. at 159-70. The discussion diverted into the duty of loyalty. Id. at 170-78. The discussion then returned briefly to the duty of care and the idea of adding a "fair dealing" component to the obligation of good faith. Id. at 178-80. At that point, the discussion was held in abeyance until the following day, at which time the drafting committee brought additional proposals to the floor. Id. The Conference next took these issues up again in the context of RUPA $\$ 103$. Id. at 397 . The assembly briefly considered a proposed change in the amendability of the duty of care. Id. at 398-400. The assembly then considered at great length four amendments of the duty of care. Id. at 426-85. Only then did the question arise of having a "manifestly unreasonable" qualifier for categorical exceptions under the duty of loyalty. Id. at 492-501. The Committee opposed the amendment in part because it would undercut the certainty they desired. Id. at 495 . But the motion passed, and the manifestly unreasonable qualifier was added to the duty of loyalty categorical exceptions. Id. at 500-01.

61. UNIF. PARTNERSHIP ACT $\S 4 X$ (Tentative Draft Jan. 9, 1989).

62. AMENDMENTS TO UPA \& 103(b)(3) (Revisions Aug. 2, 1992) [hereinafter AUG 2, 1992, RUPA REVISIONS]. 
excepted by section 103(b)." ${ }^{.63}$ At the same July 1992 meeting, the drafters included categorical modification language, but in section 404, not section 103: "A partner's duty of loyalty may not be eliminated by agreement, but the partner[s] may by agreement identify specific types or categories of activities that do not violate the duty of loyalty." had not introduced any type of qualification on the right to agree to categorical modifications, and the confirmatory reading is fully consistent with the proposed statutory language. ${ }^{65}$ The "manifestly unreasonable" condition was added at the 1992 meeting. ${ }^{66}$ But it was not added by the drafters; it was adopted by the Conference on a motion from the floor in plenary session, and over the strenuous objection of the drafting committee ${ }^{67}$ and the ABA representatives present. ${ }^{68}$

What can we learn from the floor modification? First, some participants apparently believed-whether correctly or not is an open question-that categorical modifications were the only way to modify the duty of loyalty. ${ }^{69}$ They also believed - correctly - that by using categorical modifications, the duty of loyalty could be effectively eliminated. ${ }^{70}$ The problem apparently was that none of the participants conceived of waivers that would not constitute total elimination of the duty of loyalty but that also would not be cast in terms of "types or categories of activities."

63. UNIF. PARTNERSHIP ACT $\S 404 \mathrm{cmt}$. (Tentative Meeting Draft July 30-Aug. 6, 1992).

64. AUG. 2, 1992, RUPA REVISIONS, supra note 62, § 404(c).

65. Excepting, of course, the transitional "but" which should be "and."

66. 1992 National Conference Proceedings, supra note 54, at 492-501.

67. Id.

68. Vestal, Contractarian Error, supra note 5, at 558 n. 153.

69. 1992 National Conference Proceedings, supra note 54, at 177-78. Dean Donald Weidner, the Reporter on RUPA, declared, "We do want to enforce the waiver in the initial agreement, at least at a certain level of specificity." Id.

70. Id. at $170-73,177-78,495-96$.

71. The following exchange occurred between a commissioner and a member of the drafting committee:

Commissioner: As I read this section, the partners can delete from the duty of loyalty as many different categories of activities as they can possibly think of. Is that correct? Committee Member: If they are categories as opposed to simply the complete duty itself, yes.

Commissioner: So, we could say that one of the categories is competing with the partnership.

Committee Member: No.

Commissioner: That's not a category?

Committee Member: It would have to be something like with respect to real estate transactions.

Commissioner: Okay. So, if I'm in a law partnership, I can say we'll delete from the agreement the prohibition against competition in the practice of law. You'd say that I can do that?

Committee Member: That you could compete or you could not?

Commissioner: That I could specifically say I'm going to delete from the duty of loyalty the prohibition against competing with this firm in the practice of law.

Committee Member: The answer to that would be "yes," that you could haveId. at 495-96.

Commissioner: So that cuts out the guts of the loyalty obligation. 
amendment written from the floor of a plenary session, the nuances of the modification were not carefully considered. The original suggestion was to delete the categorical modification language and to substitute in its place language providing that "the duty of loyalty may not be eliminated but you can, by agreement, determine standards by which the performance is measured so long as not manifestly unreasonable." ${ }^{72}$ The drafting committee rejected the suggestion. ${ }^{73}$ A motion followed that the categorical modification language "be amended to include a limitation on the exclusion of categories of activities, to limit those categories to ones that are not manifestly unreasonable." ${ }^{, 4}$ The committee responded that it did not want the qualification (misstated as an "unfairly unreasonable test") because the proposed language "would simply make it subject to too much uncertainty with respect to any type of exclusion that was drafted." "We were trying to make this so as you have at least some reasonable safe harbor without making it so unindefinite [sic] that it would create difficulties in terms of being able to give legal opinions and being able to have some reasonable assurance that a particular exclusion was valid." The vote from the floor added the concept, although the specific language was crafted by the drafting committee. ${ }^{77}$

The categorical modification language was not moved from section 404 to section 103 until one year later, with the drafts of July $1993{ }^{78}$ The second subsidiary clause, which addresses less-than-unanimous authorizations and ratifications of specific acts or transactions that would otherwise violate the duty of loyalty, ${ }^{79}$ first appears, in slightly different form, in a discussion draft dated December $7,1993{ }^{80}$ This was apparently prompted by an October 1993 critical comment from an ABA committee. ${ }^{81}$ The specific ratification language was inserted, in its final form, into the draft with the January 1994 draft $^{82}$ and was accepted by the Conference at its July 1994 meeting. ${ }^{83}$ The official commen-

72. Id. at 493 .

73. Id. at 494 .

74. Id.

75. Id. at 495 .

76. Id.

77. Id. at 500-01.

78. ReVISED UNIF. PARTnershiP ACt $\S 103(\mathrm{~b})(3)$ (Tentative Draft July 2, 1993); UNIF. PARTNERSHIP ACT WITH 1993 PROPOSED REVISIONS \$ 103(b)(3) (Tentative Meeting Draft July 30Aug. 6, 1993) (redlined with changes).

79. RUPA $\S 103$ (b)(ii), 6 U.L.A. at 288 (Supp. 1995). "The partnership agreement may not ... eliminate the duty of loyalty . . . but . . . (ii) all of the partners or a number or percentage specified in the partnership agreement may authorize or ratify, after full disclosure of all material facts, a specific act or transaction that otherwise would violate the duty of loyalty . ..."Id.

80. REVISED UNIF. PARTNERSHIP ACT \$103(b)(3)(ii) (Discussion Draft Dec. 7, 1993) (partnership agreement may "authorize or ratify, after full disclosure of all material facts, a specific act or transaction that otherwise would violate the duty of loyalty").

81. SUbCOMMITTEE ON RUPA, A.B.A. SEC. BUS. L., [RUPA] ADOPTED BY [NCCUSL]: SUPPLEMENTAL REPORT BY THE SUBCOMMITTEE ON RUPA, 4-5, A3-A4 (Oct. 1993) (on file with author).

82. UNIF. PARTNERSHIP ACT $\S 103$ (b)(3)(ii) (Tentative Draft Jan. 18, 1994).

83. RUPA $\$ 103($ b)(3)(ii), 6 U.L.A. at 288 (Supp. 1995). 
tary clearly states that the specific ratification language is intended to "clarify" existing law and that the provision is independent of the "manifestly unreasonable" requirement of the preceding clause. ${ }^{84}$

What can we learn from the legislative history of the "manifestly unreasonable" qualifier? The entire debate over the qualifier was flawed in that it proceeded from the linked assumptions-both incorrect in hindsight - that the duty of loyalty was protected against changes, not only outright elimination, and that the duty could be modified only by specific categorical modifications. The result of the flawed debate was a statutory provision that is internally inconsistent and imprecise. Given this confusion, the prudent course for a court reviewing the language would be to adopt the narrowest plausible construction: the confirmatory reading.

The final argument in favor of the confirmatory reading over the restrictive reading involves the parallel provision that provides for less than unanimous consent. $^{85}$ How would one read the consent provision to harmonize with the restrictive reading of the "manifestly unreasonable" qualifier? If one reads the word "eliminate" to mean "vary," as the restrictive reading requires, then one presumably reads section 103(b)(3) without the consent provision to preclude even unanimous, fully-informed, noncategorical consent. In this scheme, section 103(b)(3)(ii) is the mechanism by which noncategorical consent is authorized, and the less-than-unanimous provision is merely incidental to the central thrust of the clause. In contrast, the confirmatory reading sees section 103(b)(3)(ii) as simply confirming the existence of a way other than ex ante categorical consent to modify the statutory duty of loyalty short of its complete elimination. Under this reading, the less-than-unanimous provision is central, rather than incidental, since it varies the common law rule. Either argument is plausible, but the language of the clause favors the confirmatory reading.

\section{Summation}

Where does that leave us? Admitting that the language of section 103(b)(3) is imprecise and should be changed, however one comes out on the policy issue, the better reading is that section $103(\mathrm{~b})(3)$ permits broad contractual modifications of the statutory duty of loyalty, both in type and sweep, as long as the modifications do not completely eliminate the duty. Within that broad power to modify, the statute notes two special cases as to which the statute contains additional provisions. Consistent with the common law rule, categorical waivers are allowed, but the categories may not be "manifestly unreasonable." In a

84. Id. $\S 103 \mathrm{cmt}$ 5, 6 U.L.A. at 288 . The initial draft commentary specifically provided that a specific consent under the clause "is not subject to judicial review under the 'manifestly unreasonable" standard." RUPA \& $103 \mathrm{cmt} .2$ (Tentative Draft June 1, 1994).

85. RUPA § 103(b)(3)(ii), 6 U.L.A. at 288 (Supp. 1995) ("The partnership agreement may not . . eliminate the duty of loyalty ... but ... . all of the partners or a number or percentage specified in the partnership agreement may authorize or ratify, after full disclosure of all material facts, a specific act or transaction that otherwise would violate the duty of loyalty."). 
departure from the common law rule, less than unanimous consent may be provided for.

I think there is a plausible, even strong, argument that the contractarians got a better result than they now acknowledge. The parties can agree to the drastic weakening of the fiduciary duty of loyalty and the nonfiduciary obligation of good faith and fair dealing. Could the treatment of the "mandatory" fiduciary duties and the nonfiduciary obligation of good faith and fair dealing of partners under RUPA be any clearer? Of course it could ${ }^{86}$ Could the treatment of the "mandatory" fiduciary duties and the nonfiduciary obligation of good faith and fair dealing of partners be any weaker? Of course it could. Those provisions could be rendered fully amendable; they could be removed from the list of statutory sections as to which the parties' power to modify is restricted. This is Professor Hynes's suggestion as to the fiduciary duties, ${ }^{87}$ if not the duty of good faith. ${ }^{88}$ It is also the proposal of other contractarian commentators. ${ }^{89}$ But the fact that the RUPA formulation could be weaker does not make the existing formulation mandatory in any meaningful sense.

\section{IV}

\section{THE UNADDRESSED CHOICE: EFFICIENCY OR JUSTICE}

One barrier to compromise is that we approach these matters from very different conceptualizations of the partnership relation. Professor Hynes believes that " $[\mathrm{t}]$ he partnership relationship is most understandably viewed as a contractual relationship in all of its respects." 90 This is a defensible position, although one with which I strongly disagree. I view the partnership relation as fundamentally one of status, with contractual bargaining at the periphery. I suspect Professor Hynes would acknowledge that this, too, is a defensible position. But Professor Hynes also believes that his position "doubtless reflects the view of those who enter partnerships, that they can agree among themselves what they want their relationship to be."191 This strikes me as unlikely based

86. The full contractarian agenda could be achieved by simply deleting RUPA $\S 103(\mathrm{~b})(3)$ in its entirety. The confirmatory reading could be incorporated into the section as follows:

(b) The partnership agreement may not: ...

(3) eliminate the duty of loyalty under Section 404(b) or 603(b), but modifications of such duty may be made which do not constitute elimination, including but not by way of limitation the following.

(i) the partnership agreement may identify specific types or categories of activities that do not violate the duty of loyalty, if not manifestly unreasonable; and

(ii) all of the partners or a number or percentage specified in the partnership agreement may authorize or ratify, after full disclosure of all material facts, a specific act or transactions that otherwise would violate the duty of loyalty ....

87. "It is the view of the author that deleting the provisions in section 103 that mandate fiduciary duties would be a logical extension of the bargain principle." Hynes, supra note 2, at 50 .

88. Id. at 54.

89. Ribstein, supra note 5, at 57-61.

90. Hynes, supra note 2, at 39.

91. Id. 
on both my personal experience ${ }^{92}$ and our collective history. ${ }^{93}$ Of course, people who enter into partnerships rightly understand many facets of their relationship to be the subject of negotiation, but I rather doubt that the majority of partners view the core of the fiduciary obligations inter se to be wholly negotiable. ${ }^{94}$ If partners have such contractarian expectations, then the common law and the existing statutory regime have been seriously out of touch with lay expectations for a long, long time.

We compound the confusion, and make a compromise less likely, by not precisely defining the competing values. Professor Hynes, for example, seems to well define the efficiency-related values his proposal would advance: "the principle of freedom of contract among partners," certainty and reliability of partnership agreements." partnership agreements reliable and certain is "a worthy goal," "[w]ho can quarrel with the policy of providing certainty and reliability to partnership contracts, within the framework of limitations applicable to all contracts?"98

But what of the competing values? Professor Hynes speaks rather vaguely of "the value of a definition of fiduciary duties that would leave room for expansion and reformulation of underlying principles ..., " which, he notes, "was outweighed by the competing value of certainty and reliability of partnership agreements." 99 And no wonder; even next to low-intensity values like certainty and reliability, "expansion" and "reformulation" are hardly the kind of values that inspire much enthusiasm. But, of course, just as certainty and reliability are proxies for efficiency, expansion and reformulation are proxies for individual justice.

It certainly is true that having broad, mandatory fiduciary duties competes with unlimited freedom of contract and is, at some level, in competition with a goal of making partnership agreements more certain and reliable. Professor Hynes notes the effect of the ascendancy of efficiency. He finds the wording of the fiduciary duty definition "curious" because it confines the description of

92. I was in private practice for $\mathbf{1 0}$ years prior to becoming an academic. During that time, I represented many partnerships, from relatively uncomplicated family partnerships to joint ventures of very sophisticated high-tech corporations. On the basis of that admittedly anecdotal experience, Professor Hynes's characterization strikes me as substantially wide of the mark.

93. E.g., Meinhard v. Salmon, 164 N.E. 545, 546 (N.Y. 1928).

94. That some facets of the partnership relation are negotiable is so obvious as to not require restatement. E.g., UPA $\S 18,6$ U.L.A. at 213 ("The rights and duties of the partners in relation to the partnership shall be determined, subject to any agreement between them, by the following rules ....."). But there has always been a clear difference between the business concern of how profits and management rights are allocated, and the core fiduciary duties of loyalty, care, and good faith. But see Kende, supra note 23 , at $47 \mathrm{n} .128$ (citing UPA $\$ 18$ as evidence that "anti-contractarian" view of fiduciary duties is incorrect).

95. Hynes, supra note 2 , at 31 .

96. Id. at 32.

97. Id. at 35 .

98. Id. at 33 n.13.

99. Id. at 32 . 
fiduciary duty in an artificial way. ${ }^{100}$ He notes that the sweep of fiduciary obligation does not extend as far under RUPA as it does under the existing regime, eliminating the fiduciary obligation to supply information and cutting the duty of good faith off from its fiduciary roots to increase the reliability of agreements. ${ }^{101}$

But these are not simply abstract effects of a desire for efficiency; these are costs of substantial proportions in terms of individual fairness and justice. Cast in this way, there are any number of people who quarrel with the ascendancy of the efficiency goals of certainty and reliability over the fiduciary goals of individual fairness and justice. ${ }^{102}$

We have not yet really joined, much less resolved, these questions. ${ }^{103}$ At the counsel of the contractarians, the Conference proposes to undo the established fiduciary base of partnership law and substitute in its place an efficiency-based regime. Such a significant step should not be taken without a great deal more debate than we have had. ${ }^{104}$ We certainly ought not take such a step on the basis of the suggestion that no one "can quarrel with the policy of providing certainty and reliability to partnership contracts . ..."105

100. Id. at 31-33.

101. Id. at 33-34.

102. See Vestal, Contractarian Error, supra note 5, at 539. Commentators have noted the importance of the language in which fiduciary duties are couched:

[t]he language expressing these [fiduciary] norms is aspirational and studiously imprecise. The very ambiguity of the language conveys its moral content as the court's refusal to set lines is designed to discourage marginal conduct by making it difficult for a fiduciary to determine the point at which self-serving conduct will be prohibited, and thus to encourage conduct well within the borders.

Lawrence E. Mitchell, The Death of Fiduciary Duty in Close Corporations, 138 U. PA. L. REV. 1675, 1695-96 (1990); see also Tamar Frankel, Fiduciary Law, 71 CAL. L. REV. 795, 829-32 (1983); Marleen A. O'Connor, How Should We Talk About Fiduciary Duty? Directors' Conflict of Interest Transactions and the American Law Institute's Principles of Corporate Governance, 61 GEO. WASH. L. REV. 954 (1993). Professor Deborah DeMott adds an appropriate cautionary note about substituting metaphor for analysis. Deborah A. DeMott, Beyond Metaphor: An Analysis of Fiduciary Obligation, 1988 DUKE L.J. 879.

103. An interesting body of literature is developing that confronts the law and economics infatuation with efficiency. See Claire Moore Dickerson, From Behind the Looking Glass: Good Faith, Fiduciary Duty and Permitted Harm, 22 FLA. ST. U. L. REV. 955 (1995) (developing permitted harm analysis); Tamar Frankel, Fiduciary Duties as Default Rules (inappropriate to use fiduciary duties as default rules) (on file with author).

104. The ABA committee that initiated the partnership law revision effort did not call for such a basic change. It wanted the new statute "to incorporate the full range of fiduciary duties developed by the cases (due care, good faith, loyalty, and full disclosure of all material facts)." Uniform Partnership Act Revision Subcommittee, ABA Business Law Section, Should the Uniform Partnership Act be Revised, 43 BUS. LAW. 121, 151 (1987). The committee also recommended that "[t]he extent of the fiduciary duty of a particular partner should be able to be limited (or expanded) by agreement between the partners." Id. at 152 .

105. Hynes, supra note 2, at 33 n.13. 


\section{$\mathrm{V}$ \\ THE ILLUSION OF COMPROMISE: UNCONSCIONABLE CATEGORICAL WAIVERS AND RELIANCE ON·A "MANDATORY" AND NARROWLY DEFINED OBLIGATION OF GOOD FAITH}

To his credit, Professor Hynes is not inflexible about fixing RUPA. Although he argues that deleting the "mandatory" fiduciary duties under section 103 would be the logical extension of the bargain principle, ${ }^{106}$ he presents a three-part compromise solution. First, retain the current "mandatory" fiduciary duties under RUPA. ${ }^{107}$ Second, change the categorical waiver standard from "manifestly unreasonable" to "unconscionable," to better reflect the bargain principle. ${ }^{108}$ Third, narrowly define the "mandatory" obligation of good faith. $^{109}$ This solution, he has suggested, may be the best compromise available for the efficiency-seeking commentators. ${ }^{110}$

The problem with Professor Hynes's compromise proposal is that it does not represent a genuine compromise at all. His first point, and presumably his primary concession to the fiduciary analysis, is to allow the continuation of the existing mandatory fiduciary duties, which are neither mandatory nor truly fiduciary. ${ }^{11}$ His second point is to make the categorical waiver language even less protective of aggrieved partners. His third point is to rely on what he erroneously sees as a "mandatory" obligation of good faith, which he proposes to define narrowly. We have already addressed the first point; let us turn to the second and third.

\section{A. Categorical Waivers: Manifestly Unreasonable or Unconscionable?}

Assume, for the moment, that Professor Hynes is correct that the manifestly unreasonable test applies to all modifications of the statutory duty of loyalty. Does it make sense to move to an unconscionability test? The term "manifestly unreasonable" is not defined in RUPA, and we are given little guidance in the official commentary. ${ }^{112}$ Professor Hynes worries that the phrase invites judges and juries to substitute their personal "assessment of the reasonableness of a term" for a more orderly consideration. ${ }^{13}$ The unconscionability test appeals to him because it has a better developed body of interpretation, and-importan-

106. Id. at $39-46,50$.

107. Id. at 50 .

108. Id. at 50-53.

109. Id. at $36-49$.

110. Hynes, supra note 6 (concluding his proposal "may be the best compromise available").

111. Vestal, Contractarian Error, supra note 5, at 545-55, 556-63. See infra part II

112. RUPA $\$ 103 \mathrm{cmt}$. 5, 6 U.L.A. at 288 (Supp. 1995). Professor Hynes observes that the term is not the subject of helpful case decisions. Hynes, supra note 2, at $53 \mathrm{n} .110$.

113. Hynes, supra note 1 , at 51-52. 
tly-because it has a process predicate. ${ }^{114}$ Professor Hynes candidly acknowledges a final point of comparison:

[I]n addition to the doctrinal distinctions[,] . . : one can point to the shock value of the word "unconscionable" as a point of difference between the two tests. . . " [U]nconscionable" defines a more extreme situation than the milder "manifestly unreasonable." By doing so, it elevates the stakes and enhances the inquiry. That in turn accords greater respect to the agreement. ${ }^{115}$

Professor Hynes's proposal should not appeal to either side in this debate for two of the very reasons for which he favors the substitution. The fiduciarybased objection is clear. By "defining a more extreme situation," "elevating the stakes," "enhancing the inquiry," and "according greater respect to the agreement," Professor Hynes presumably means that an unconscionability showing would be harder to make than a showing of manifest unreasonableness, thus affording partners even further diminished protection. In this he is probably right, and for this reason, fiduciary-oriented commentators, who already object to the diminution of protection from the UPA to RUPA, should oppose his proposal.

If the contractarians are worried about the theory involved and are not simply aiming to set the bar as high as possible, they should be concerned about the process inquiry involved in application of an unconscionability standard. The partners' fiduciary obligations extend to the pre-partnership negotiation phase under the UPA ${ }^{116}$ but not under RUPA. ${ }^{117}$ It is inconsistent with the evolution of partnership law, then, to move to an unconscionability standard that would look into the negotiation phase.

There is also a process problem concerning how an unconscionability standard would interact with RUPA section 404(f), the approval of selfdealing. ${ }^{118}$ This could easily arise where a partner transacted business with the partnership claiming protection of a categorical waiver. ${ }^{119}$ Another partner could seek to enforce the duty of loyalty provisions against self-dealing ${ }^{120}$ and could challenge the categorical waiver on unconscionability grounds. ${ }^{21}$ The unconscionability standard is contextual, and the identity of the partner as a partner is a critical part of that context. ${ }^{122}$ An unconscionability standard and

114. Id. at 52-53.

115. Id. at 53.

116. Vestal, Contractarian Error, supra note 5, at 529 n.16.

117. RUPA $\$ 404$ (b)-(c), 6 U.L.A. at 313 (Supp. 1995).

118. Id. $\S 404(\mathrm{f}), 6$ U.L.A. at 313 ("A partner may lend money to and transact other business with the partnership, and as to each loan or transaction the rights and obligations of the partner are the same as those of a person who is not a partner, subject to other applicable law.").

119. Id. \& 103(b)(3)(i), 6 U.L.A. at 288.

120. Id. $\S 404(\mathrm{~b})(1)-(3), 6$ U.L.A. at 313.

121. Id. $\$ 103(\mathrm{~b})(3)(\mathrm{i}), 6$ U.L.A. at 288 (modified for this example by substitution of an unconscionability test for the current statutory manifestly unreasonable test).

122. RESTATEMENT (SECOND) OF CONTRACTS \& $208 \mathrm{cmt}$. a (1979). "The determination that a contract or term is or is not unconscionable is made in the light of its setting, purpose and effect." Id.

"Some types of terms are not enforced, regardless of context.... Other terms may be unconscionable in some contexts but not in others." Id. $\S 208 \mathrm{cmt}$. e. There are unconscionability cases whose 
the self-dealing provision of section $404(f)$ could be reconciled in two very different ways. The categorical approval language, as tied to an unconscionability standard, could put the partner seeking to overturn a categorical waiver on unconscionability grounds to an unconscionability test that considered his or her status as partner. In the alternative, section 404(f) could be read to alter the unconscionability test fundamentally by abandoning the contextual component and substituting in its place a wholly idiosyncratic and artificial test using fictional nonpartners. The difference could easily be outcome determinative.

\section{B. Is a Mandatory Good Faith Standard Sufficient Protection?}

I suspect Professor Hynes views this component of his proposed compromise as a trade. The contractarians submit to a mandatory obligation of good faith, and the fiduciary commentators agree to give up RUPA's open-ended definition of good faith and fair dealing and submit to a narrow, UCC-based definition.

The initial problem with this view is that the nonfiduciary obligation of good faith and fair dealing as it exists in RUPA is no more mandatory than the fiduciary duty of loyalty. The obligation of good faith suffers from the same questions regarding amendability as the duty of loyalty. As is the duty of loyalty, the obligation of good faith and fair dealing is listed as a section of RUPA as to which the parties' power to modify is restricted. ${ }^{123}$ As is the duty of loyalty, the obligation of good faith and fair dealing is protected only to the extent that the parties may not "eliminate" it, ${ }^{124}$ and the parties are free to agree to a specific class of modifications with the requirement that such modifications may not be "manifestly unreasonable."125 As with the duty of loyalty, the language of the RUPA provision is imprecise and admits both a restrictive and a confirmatory reading. ${ }^{126}$ Regardless of how one personally resolves the issue, the "mandatory" nature of the obligation of good faith and fair dealing is far too tenuous to form the basis of a compromise such as that outlined by Professor Hynes.

The second problem with Professor Hynes's good faith compromise is his advocacy of a narrow definition of good faith. He is correct that RUPA does not define the obligation of good faith and fair dealing, electing to leave the

outcomes strongly suggest consideration of the partnership setting. See, e.g., Bohn v. Bohn Implement Co., 325 N.W.2d 281, 282, 285 (N.D. 1982).

123. RUPA § 103(b)(5), 6 U.L.A. at 288 (Supp. 1995).

(b) The partnership agreement may not: ...

(5) eliminate the obligation of good faith and fair dealing under Section 404(d), but the partnership agreement may prescribe the standards by which the performance of Id. the obligation is to be measured, if the standards are not manifestly unreasonable.

124. Id. § 103(b)(5), 6 U.L.A. at 288.

125. Id.

126. See supra part II. 
development of the law up to the courts. ${ }^{127} \mathrm{He}$ is also correct that this choice is at odds with certainty. ${ }^{128}$ His solution, to advance certainty, is to adopt the general UCC definition of "good faith" as "honesty in fact in the conduct or transactions involved." 129 This desire for efficiency has apparently overridden Professor Hynes's earlier doubts; he once rejected the UCC definition, concluding that it "seems too narrow for the variety of situations which the definition in section 404(a) would encompass." ${ }^{130}$ Professor Hynes was not alone in rejecting the narrow UCC definition; the Conference drafters considered and rejected a move by the $\mathrm{ABA}$ participants to include the restrictive definition of good faith. ${ }^{131}$ If partners are left to rely on the good faith standard, then that standard ought not be further weakened by adopting a definition too narrow to deal with the situations one reasonably anticipates will arise.

A third problem with reliance on the nonfiduciary obligation of good faith concerns two other RUPA provisions that appear to undermine the good faith obligation. The first is RUPA's endorsement of self-interest: "A partner does not violate a duty or obligation under this [Act] or under the partnership agreement merely because the partner's conduct furthers the partner's own interest." 132 How does one reconcile this affirmation of self-interest-which clearly is intended to trump the obligation of good faith in some situations-with increased reliance on the good faith and fair dealing obligation? The second provision is RUPA's approval of self-dealing: "A partner may lend money to and transact other business with the partnership, and as to each loan or transaction the rights and obligations of the partner are the same as those of a person who is not a partner, subject to other applicable law."133 The same type of problem is raised here as with the unconscionability test for categorical waivers. The problem is that the obligation of good faith and fair dealing is undoubtedly contextual, and the identity of the partner as a partner is a critical

127. RUPA § 404 cmt. 4, 6 U.L.A. at 313 (Supp. 1995).

The meaning of "good faith and fair dealing" is not firmly fixed under present law. "Good faith" clearly suggests a subjective element, while "fair dealing" implies an objective component. It was decided to leave the terms undefined in the Act and allow

Id. the courts to develop their meaning based on the experience of real cases.

128. Hynes, supra note 1 , at 47 .

129. Id. ("To minimize the danger of uncertainty, 'good faith' is best defined as it is in Article 1 of the Uniform Commercial Code, as 'honesty in fact in the conduct or transactions concerned."). Professor Hynes proposes incorporation of the general UCC definition of good faith, "honesty in fact in the conduct or transaction concerned." U.C.C. § 1-201(19) (1990). It is unclear whether he would adopt the Article 2 definition of good faith for a merchant, "honesty in fact and the observance of reasonable commercial standards of fair dealing in the trade," id. §2-103(1)(b), where the partner is a merchant within the definition of U.C.C. $\$ 2-104(1)$. This could make a substantial difference in partnerships where one partner provides capital and another provides expertise in the business of the partnership.

130. Hynes, supra note 5, at 756 n. 124.

131. Vestal, Contractarian Error, supra note 5, at 549 n. 103.

132. RUPA $\S 404(\mathrm{e}), 6$ U.L.A. at 313 (Supp. 1995).

133. Id. $\S 404(\mathrm{f}), 6$ U.L.A. at 313. 
part of that context. The basic UCC good faith requirement, which Professor Hynes proposes to incorporate into RUPA, is a subjective rather than objective standard. ${ }^{134}$ The good faith and fair dealing requirement of RUPA section 404(d), interpreted as the UCC provides, and the self-dealing provision of RUPA section 404(f) could be reconciled in two very different ways. The Revised Act provision could put the knowledgeable partner to the subjective good faith standard of the UCC, which requires consideration of his or her status as partner. In the alternative, the Revised Act could be read to alter fundamentally the UCC's good faith requirement by abandoning the wellestablished subjective good faith standard and substituting in its place a wholly idiosyncratic "reasonable (nonpartner) person standard." ${ }^{35}$ The first reading is more plausible, since the statutory language gives no indication of such a radical change in existing law. The official commentary is ambiguous. ${ }^{136}$

This last problem is illustrative of a more general difficulty with RUPA, the lack of a consistent answer to the tension between the competing goals of efficiency and individual justice. Not that RUPA ought to pursue either goal to the exclusion of the other, but RUPA is frequently unclear, once a balance has presumably been struck, as to what that balance is. ${ }^{137}$

\section{VI \\ CONCLUSION}

Where do we go from here? It should be clear that the process has broken down, that RUPA as it stands is not-and should not be-acceptable to either the contractarians or those who maintain the importance of fiduciary principle. It is a measure of how inadequate that process has been that we are debating this late in the day whether RUPA takes partners from mandatory fiduciary rules to default rules, or the other way around. It is also a measure of how

134. See Farmers Coop. Elevator, Inc., Duncombe v. State Bank, 236 N.W.2d 674, 678 (Iowa 1975) ("Decisions construing $\$ 1201$ (19) of the Code overwhelmingly agree that the test of good faith under that section is a wholly subjective one of honesty." (citing cases establishing subjective standard)).

135. The general contractual duty of good faith and fair dealing is similarly contextual. RESTATEMENT (SECOND) OF CONTRACTS § $205 \mathrm{cmt}$. a (1979) (citing U.C.C. § 1-201(19) (1990) (definition of good faith)). In the Restatement (Second) model, "[g]ood faith performance or enforcement of a contract emphasizes faithfulness to an agreed common purpose and consistency with the justified expectations of the other party." Id.

136. RUPA \& 404 cmt. 6, 6 U.L.A. at 313 (Supp. 1995).

Subsection (f) authorizes partners to lend money to and transact other business with the partnership and, in so doing, to enjoy the same rights and obligations as a nonpartner. ... The rights and obligations of a partner doing business with the partnership as an outsider are expressly made subject to the usual laws governing those transactions. ... The reference to "other applicable law" makes clear that subsection (f) is not intended to displace those laws, and thus they are preserved under Section Id. 104(a).

137. The fiduciary duties illustrate one important point upon which contractarian analysis has failed to carry the day. Another is the disclosure obligations of partners inter se. Vestal, Contractarian Failing, supra note 5. 
flawed the product is that the statute provides no clear direction to partners and their attorneys on these critical questions.

Professor Hynes searches for compromise. That goal is correct, although his proffered compromise is really just tinkering with the contractarian failure of RUPA and moving the regime toward a marginally more contractarian end. But if we want real compromise to get us out of this awkward situation, there is a way. ${ }^{138}$

First, the Conference and the ABA should admit impasse and withdraw RUPA. As this article is written, the various states are considering RUPA. They are making fundamental changes in the statute in an uncoordinated and nonuniform way. Rather than have this breakdown continue, with the resulting nonuniformity and confusion in the law, and the inevitable resentment when another uniform act is promulgated in a very few years, the states should be urged to cease their consideration of RUPA.

Second, RUPA should be rewritten to include two divisions. The first should be the foundational law of general partnerships. While it could incorporate large parts of RUPA, and thus take advantage of much of the valuable work done by the Conference drafting committee, it should differ from RUPA by being based on a fiduciary model of the partners' relations inter se. Within that area, it should include a nonexclusive, broad statement of the partners' fiduciary duties inter se. It should include both the obligation to disclose relevant information and the obligation to act in good faith as fiduciary duties. It should apply from the prepartnership phase through winding up. And its fiduciary duties should be amendable only by written agreements, either categorical or specific, either ex ante or ex post, but always with full disclosure of all material facts, and only to the extent not manifestly unfair or unreasonable, either in isolation or in aggregate.

In contrast, the second division should provide for an opt-in, contractarianbased modification of key provisions of the first division. Parties could opt in at any time, but the election would have to be in writing. By opting in, the parties would be subject to an exclusive, limited statement of the partners' duties inter se, and no limitation would be imposed on the authority of the partners to modify the statutory default duties. The opt-in regime would include reduced default disclosure obligations and restricted temporal application, both fully amendable. There would be no standards for enforcement of the parties' modification agreements other than the otherwise applicable contract standards of unconscionability, good faith and the like. To avoid confusion, business organizations which opt into the contractarian regime would be designated "statutory joint ventures."

Under such an approach, both sides get much, but not all, of what they desire. The contractarians get a regime with clear defaults, which follow the

138. This proposal incorporates many elements I have suggested before. Vestal, supra note 7, at 769 73; Vestal, Contractarian Error, supra note 5, at 578. 
hypothetical cost-free negotiation of contractarian theory, and the ability for partners to bargain to pretty much whatever end they desire. They get the measure of predictability and certainty they require, and the efficiency they crave. The advocates of traditional fiduciary partnership law get a fiduciary regime for inadvertent partners and for those who do not opt in to the contractarian regime, with its purposefully broad definitions of duty, its flexibility to meet new situations, and its capacity to work toward an individually just result. They avoid the debasement of the partnership concept found in RUPA. There are also process reasons favoring this compromise. With it, we may be able to avoid a breakdown in uniformity in partnership law. By linking limited partnership law to the first division, we could avoid the necessity of rewriting limited partnership law into a comprehensive, stand-alone statute. ${ }^{139}$

Professor Hynes is right that compromise is needed to solve the problems with RUPA. His analysis and proposed compromise are flawed, but he has nevertheless made a significant contribution to a much-needed discussion.

139. See Vestal, CULPA, supra note 5. 
